\title{
Nitrogen fixation-enhanced carbon sequestration in low nitrate, low chlorophyll seascapes
}

\author{
David M. Karl ${ }^{1, *}$, Ricardo M. Letelier ${ }^{2}$ \\ ${ }^{1}$ Department of Oceanography, University of Hawaii, Honolulu, Hawaii 96822, USA \\ ${ }^{2}$ College of Oceanic and Atmospheric Sciences, Oregon State University, Corvallis, Oregon 97331, USA
}

\begin{abstract}
The magnitude of fluxes in the carbon cycle of subtropical and tropical marine habitats is determined by the supply of inorganic nutrients. These habitats have low sea-surface concentrations of nitrate $\left(\mathrm{NO}_{3}^{-}\right)$and chlorophyll (dubbed LNLC regions), sustain relatively low rates of organic matter production and export, and represent global ocean minima in carbon sequestration potential. The low $\mathrm{NO}_{3}{ }^{-}$resupply should select for nitrogen $\left(\mathrm{N}_{2}\right)$-fixing bacteria, termed diazotrophs, provided all other growth-limiting nutrients are available. Several recent field efforts have been aimed at enhancing $\mathrm{N}_{2}$ fixation in LNLC regions through mesoscale fertilization with iron and phosphorus (or both) and we hypothesize herein that controlled upwelling of nutrient-enriched deep water may also be effective. Based on a quantitative assessment of the vertical distribution of $\mathrm{NO}_{3}{ }^{-}$, phosphate $\left(\mathrm{PO}_{4}{ }^{3-}\right)$ and dissolved inorganic carbon (DIC) at Station ALOHA $\left(22^{\circ} 45^{\prime} \mathrm{N}, 158^{\circ} \mathrm{W}\right)$, we hypothesize that the process of controlled upwelling of low $\mathrm{NO}_{3}{ }^{-}: \mathrm{PO}_{4}{ }^{3-}$ seawater may lead to enhanced $\mathrm{N}_{2}$ fixation, organic matter production and net carbon sequestration. Furthermore, based on a long-term $(20 \mathrm{yr})$ data set from Station ALOHA, we predict that the upwelling of water from a depth of 300 to $350 \mathrm{~m}$ during summer months will trigger a 2-stage phytoplankton bloom. The first stage will be characterized by a $\mathrm{NO}_{3}{ }^{-}$-supported Redfield ratio (e.g. $\mathrm{C}_{106}: \mathrm{N}_{16}: \mathrm{P}$ by atoms) diatom bloom. Following quantitative $\mathrm{NO}_{3}{ }^{-}$removal, the residual $\mathrm{PO}_{4}{ }^{3-}$ from the low $\mathrm{N}: \mathrm{P}(<16: 1)$ upwelled nutrient pulse will stimulate a $\mathrm{N}_{2}$-fixing bacterial bloom, leading to net sequestration of carbon. However, any strategic benefit of controlled upwelling for enhancing the long-term carbon sequestration will depend on the spatial and temporal uncoupling of organic matter production and remineralization, which is ultimately controlled by the microbial response to these perturbations.
\end{abstract}

KEY WORDS: $\mathrm{N}_{2}$ fixation - Diazotroph - Nutrients - Carbon sequestration - North Pacific gyre Resale or republication not permitted without written consent of the publisher

\section{$\mathrm{N}_{2}$ FIXATION IN OCEANIC HABITATS}

Nearly $80 \%$ of the surface waters of the global ocean are considered nitrate $\left(\mathrm{NO}_{3}{ }^{-}\right)$-depleted $\left(\leq 1 \mu \mathrm{M} \mathrm{NO}_{3}{ }^{-}\right)$. These regions, located between $30^{\circ} \mathrm{N}$ and $30^{\circ} \mathrm{S}$ in every ocean basin, are characterized by low $\mathrm{NO}_{3}{ }^{-}$ delivery, low standing stocks of particulate matter (including living organisms) and low rates of new and export production (Longhurst 1998). A strong vertical stratification insulates the upper layers of these vast seascapes from the large pool of $\mathrm{NO}_{3}{ }^{-}$in deeper waters; e.g. in the North Pacific subtropical gyre (NPSG) a maximum concentration of approximately $42 \mu \mathrm{M} \mathrm{NO}_{3}{ }^{-}$is observed at $1000 \mathrm{~m}$ depth, whereas
$\mathrm{NO}_{3}{ }^{-}$concentrations in the upper $100 \mathrm{~m}$ are generally $<5 \mathrm{nM}$ (Fig. 1). Chronic $\mathrm{NO}_{3}{ }^{-}$limitation in the upper layer of the water column, where light is available to support photosynthesis, should select for microorganisms that are able to utilize the fairly large, but as yet poorly characterized, pool of dissolved organic nitrogen (DON, $\sim 5 \mu \mathrm{M}$ ) or the unlimited supply of dissolved $\mathrm{N}_{2}(>400 \mu \mathrm{M})$ as a source of cellular $\mathrm{N}_{\text {; }}$ the latter process is termed $\mathrm{N}_{2}$ fixation and the microorganisms responsible for it are termed diazotrophs.

$\mathrm{N}_{2}$-based new production requires an ample supply of energy, iron $(\mathrm{Fe})$ and phosphorus $(\mathrm{P})$. In marine ecosystems, the primary source of energy appears to be light; i.e. most marine diazotrophs are also phototrophs 
a

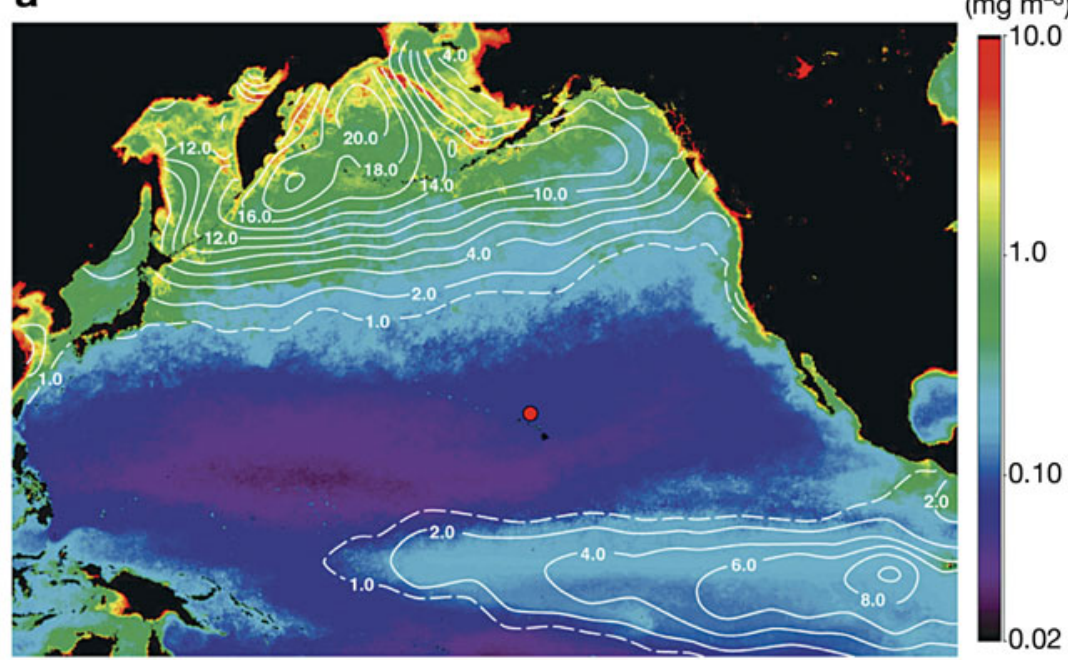

b

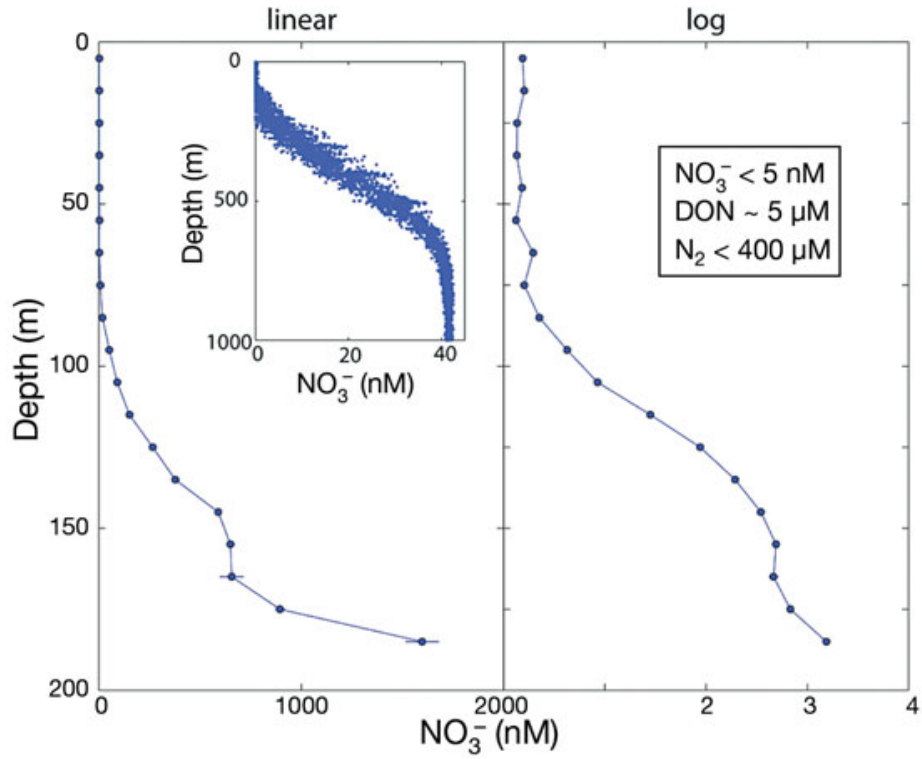

Fig. 1. (a) North Pacific Ocean with sea surface distributions of chlorophyll (mg $\mathrm{m}^{-3}$ ) derived from the AQUA MODIS satellite-based sensor system $(4 \mathrm{~km}$ resolution). Superimposed on ocean color, in white contour lines, is the mean annual surface nitrate concentration ( $\mathrm{mmol} \mathrm{NO}_{3}^{-} \mathrm{mg} \mathrm{m}^{-3}$ ) based on the World Ocean Atlas Ocean Climate Laboratory/NODC (http://www.nodc.noaa.gov/OC5/). Areas of high $\mathrm{NO}_{3}{ }^{-}$(and presumably $\mathrm{NO}_{3}{ }^{-}$flux) correspond to regions that are enriched in chlorophyll as a result of phytoplankton growth. Red circle indicates the approximate location of Station ALOHA $22^{\circ} 45^{\prime} \mathrm{N}, 158^{\circ} \mathrm{W}$, a typical low-nitrate, lowchlorophyll (LNLC) habitat. (b) Mean concentrations of $\mathrm{NO}_{3}{ }^{-}$versus water depth for samples collected at Station ALOHA during 1989-2006 plotted on both linear and logarithmic $\left(\log _{10}\right)$ scales to show details of the profile. Inset (left-hand plot) shows the $\mathrm{NO}_{3}{ }^{-}$concentration profile to $1000 \mathrm{~m}$. Compared to the low $(<5 \mathrm{nM})$ surface water concentrations of $\mathrm{NO}_{3}$, dissolved organic nitrogen (DON) and dissolved $\mathrm{N}_{2}$ are in ample supply but not readily available (see box in right-hand plot)

(Karl et al. 2002). Fe is an obligate co-factor for the enzyme nitrogenase and it has been estimated that diazotrophs may require an order of magnitude more Fe for growth than eukaryotic phytoplankton growing on ammonium as a source of nitrogen (Kustka et al. 2003). Although phosphate $\left(\mathrm{PO}_{4}{ }^{3-}\right)$ is considered to be the pre- ferred P substrate for the growth of marine microorganisms (including diazotrophs), selected P-containing organic compounds can also be used. In this study, we will use measured $\mathrm{PO}_{4}{ }^{3-}$ concentrations as a lower limit on bioavailable $\mathrm{P}$, acknowledging that the true concentrations may be at least twice as high (Björkman \& Karl 2003). If solar energy, Fe and $\mathrm{P}$ all were present in excess, phototrophic diazotrophs would have a competitive growth advantage in low $\mathrm{NO}_{3}^{-}$habitats worldwide. As diazotrophs grow, their metabolism decouples the $\mathrm{N}$ and $\mathrm{P}$ cycles by providing new $\mathrm{N}$ in the absence of deep mixing and, over time, their net growth would remove all bioavailable $\mathrm{P}$ from the ecosystem as long as $\mathrm{Fe}$ and all other required nutrients are in sufficient supply. Any $\mathrm{P}$ remaining is termed residual $\mathrm{P}(\mathrm{r}-\mathrm{P})$. Therefore, based on the constraints imposed by the C:P stoichiometry in the production of organic matter, the concentration of $\mathrm{r}-\mathrm{P}$ in a given habitat can be used as a measure of the potential for $\mathrm{CO}_{2}$ sequestration by $\mathrm{N}_{2}$ fixation.

The pathways for Fe and P resupply to the surface ocean are governed by distinct environmental forcings (Karl 2002). Whereas both Fe and $P$ are delivered from deep water to the surface by diffusion and turbulent mixing in the upper thermocline, $\mathrm{Fe}$ is also supplied from atmospheric deposition of dust. Furthermore, some dust sources (e.g. selected Saharan desert soils) contain both Fe and P (Ridame \& Guieu 2002). Because the atmosphere-to-ocean Fe flux is approximately an order of magnitude larger in the northern hemisphere than in the southern hemisphere and is larger in the North Atlantic than in the North Pacific (Duce \& Tindale 1991, Jickells et al. 2005), $\mathrm{NO}_{3}{ }^{-}$-stressed environments in the South Pacific gyre tend to have much higher r-P (>150 nM; Moutin et al. 2008) than either the NPSG (10-100 nMi Karl et al. 2001) or the North Atlantic subtropical gyre ( $<1 \mathrm{nM}$; Wu et al. 2000). Consequently, rates of $\mathrm{N}_{2}$-based new and export production can vary geographically and may have regionally distinct environmental controls. Dissolved Fe concentrations in the NPSG exhibit 'nutrient-like' profiles with 
minimum concentrations ( 0.2 to $0.4 \mathrm{nM}$ ) in near-surface waters, increasing to values of 0.7 to $1.0 \mathrm{nM}$ at approximately $1000 \mathrm{~m}$ (Johnson et al. 1997, Wu et al. 2001). In addition, and as a result of the atmospheric deposition of Fe-containing dust, near-surface waters have elevated - but much more time-variable - Fe concentrations relative to those found in the lower portion of the euphotic zone (Boyle et al. 2005). Nevertheless, quantifying bioavailability of $\mathrm{Fe}$ in marine ecosystems is difficult due, in part, to the presence of colloidal Febinding organic ligands (Wu et al. 2001) of unknown availability to microorganisms.

Superimposed on this complex network of Fe sources and sinks, r-P concentrations within the euphotic zone of the NPSG also display significant intra-seasonal as well as decadal-scale variability (Karl 2007a), emphasizing the temporal context of nutrient control of microbial dynamics. Ultimately, the concentration of r-P in low $\mathrm{NO}_{3}{ }^{-}$seascapes will depend on the extent of $\mathrm{N}_{2}$ based new production, which, in turn, constrains carbon export and sequestration, and is controlled by both the availability of energy (e.g. solar radiation and upper water column stratification) and the resupply of Fe.

In theory, there are at least 2 experimental manipulations that could be employed to stimulate the growth of marine diazotrophs in well-stratified low- $\mathrm{NO}_{3}{ }^{-}$, lowchlorophyll (LNLC) subtropical pelagic habitats and promote the sequestration of $\mathrm{CO}_{2}$ : (1) fertilization of the surface ocean with $\mathrm{Fe}, \mathrm{PO}_{4}{ }^{3-}$ or both, depending upon the ambient concentrations and in situ fluxes of both elements relative to cell needs and (2) controlled upwelling of Fe-enriched deep waters that have a low $\mathrm{NO}_{3}{ }^{-}: \mathrm{PO}_{4}{ }^{3-}$ molar ratio $(<16: 1)$ and, therefore, a relative excess of P. Successful application of either nutrient perturbation for the purpose of net $\mathrm{CO}_{2}$ sequestration would be site- and depth-specific, and perhaps seasonally dependent. While the theory of $\mathrm{N}_{2}$-based $\mathrm{CO}_{2}$ sequestration appears sound, field application might not be as straightforward and the outcomes are difficult to predict given our current understanding of microbial biogeochemical processes and ecosystem function in LNLC habitats. For this reason, nutrient manipulations should be treated as hypotheses that are amenable to direct field experimentation and quantification.

\section{OCEAN Fe/P FERTILIZATION}

In well-illuminated and stratified $\mathrm{NO}_{3}{ }^{-}$-depleted oceanic regions that contain $\mathrm{r}-\mathrm{P}$, the addition of $\mathrm{Fe}$ should enhance the growth of diazotrophs and promote $\mathrm{N}_{2}$-based carbon export and sequestration. Target regions for these studies include Fe-depleted, denitrified water masses (e.g. eastern tropical North Pacific) or oceanic gyres far removed from continental dust sources (e.g. South Pacific subtropical gyre). Alternatively, the addition of $\mathrm{PO}_{4}{ }^{3-}$ to Fe-containing, P-depleted waters also should stimulate $\mathrm{N}_{2}$ fixation. Regions with these characteristics include oligotrophic waters downwind from continental dust sources (e.g. eastern Mediterranean Sea, North Atlantic subtropical gyre, South China Sea) or areas impacted by hydrothermal inputs of Fe from shallow underwater volcanoes. Furthermore, it is important to emphasize that $\mathrm{PO}_{4}{ }^{3-}$ fertilization of Fesufficient regions may require much larger nutrient loads than Fe fertilization of P-sufficient habitats because of the relatively high P:Fe molar stoichiometry of living organisms ( $\mathrm{P}: \mathrm{Fe} \geq 10^{2}$; Ho et al. 2003). The addition of $\mathrm{PO}_{4}{ }^{3-}$ for the purpose of enhancing $\mathrm{N}_{2}$-based carbon export and sequestration would, therefore, impose a significant logistical constraint and greater expense compared to Fe fertilization. However, even in seascapes that contain measurable r-P, the impact of Fe fertilization would be enhanced if additional $\mathrm{PO}_{4}{ }^{3-}$ was added simultaneously due to the possibility of $\mathrm{Fe}$ and $\mathrm{PO}_{4}{ }^{3-}$ co-limitation of $\mathrm{N}_{2}$ fixation (Sañudo-Wilhelmy et al. 2001, Mills et al. 2004). Consequently, the autotrophic biomass response and concomitant $\mathrm{CO}_{2}$ sequestration potential will ultimately scale on the total $\mathrm{P}$, i.e. the sum of the r-P plus added $\mathrm{PO}_{4}{ }^{3-}$ concentrations.

To date, there have been 2 open ocean field trials designed to assess the Fe/P fertilization effects on microbial assemblages and elemental fluxes: (1) $\mathrm{PO}_{4}{ }^{3-}$ addition to an Fe-sufficient portion of the eastern Mediterranean Sea (CYCLOPS project; Thingstad et al. 2005) and (2) $\mathrm{Fe}$ and $\mathrm{Fe} / \mathrm{PO}_{4}{ }^{3-}$ additions to a region in the Northeast Atlantic Ocean (FeeP project; Rees et al. 2007).

\section{Cycling of phosphorus in the Mediterranean (CYCLOPS) project}

Following the addition of $\mathrm{PO}_{4}{ }^{3-}$ to increase the r-P concentration by nearly 2 orders of magnitude (to $110 \mathrm{nM}$ ) in an approximately $16 \mathrm{~km}^{2}$ patch within an ultraoligotrophic warm-core eddy, there was a $40 \%$ decrease (rather than a predicted 40 -fold increase) of chlorophyll during the first $6 \mathrm{~d}$, relative to an unfertilized control station (Thingstad et al. 2005). However, while parallel on-deck incubations amended with $\mathrm{PO}_{4}{ }^{3-}$ did not display significant changes, those amended with $\mathrm{PO}_{4}{ }^{3-}$ plus ammonium yielded a $>9$-fold increase in chlorophyll (Zohary et al. 2005), suggesting $\mathrm{N}$ and $\mathrm{P}$ co-limitation in selected non-diazotrophic phytoplankton taxa. Furthermore, in situ $\mathrm{N}_{2}$ fixation was enhanced by only $48 \%$ following $\mathrm{PO}_{4}{ }^{3-}$ addition and was unaffected by Fe addition (Rees et al. 2006), indicating that $\mathrm{P}$, rather than $\mathrm{Fe}$, was the primary limit- 
ing factor for $\mathrm{N}_{2}$ fixation. These unexpected and still unexplained results from the CYCLOPS project require further elaboration and perhaps the development of a new trophic model (Thingstad et al. 2005). Additional considerations include the competition between phytoplankton and heterotrophic bacteria and the coupling to higher trophic levels, as well as the potential role of other essential trace metals and organic compounds (e.g. vitamins) in establishing the carrying capacity of the pelagic ecosystem. questration in the open sea. Upwelling of deep waters could be implemented using a passive, wave-powered pump (Isaacs et al. 1976) or via conventional mechanical pumping. Critics of this procedure for the purpose of $\mathrm{CO}_{2}$ sequestration (e.g. Shepherd et al. 2007) were quick to point out that, along with the production-supporting nutrients (e.g. $\mathrm{NO}_{3}{ }^{-}, \mathrm{PO}_{4}{ }^{3-}, \mathrm{Fe}$ ), deep waters also contain elevated concentrations of dissolved inorganic carbon (DIC, also referred to as total $\mathrm{CO}_{2}$ ) derived from the longterm decomposition of sinking particulate matter (Fig. 2). Consequently, most natural upwelling regions are net sources of $\mathrm{CO}_{2}$ to the atmosphere (Takahashi et al. 1997).

\section{FeeP project}

During FeeP, 2 experimental patches, each approximately $25 \mathrm{~km}^{2}$, were created and studied over a $3 \mathrm{wk}$ period. The first patch contained only $\mathrm{PO}_{4}{ }^{3-}$ while the second was seeded with Fe at first, followed by a pulse of $\mathrm{PO}_{4}{ }^{3-}$ after $24 \mathrm{~h}$. The experimental concentrations were $200 \mathrm{nM}$ $\mathrm{PO}_{4}{ }^{3-}$ and $3 \mathrm{nM}$ Fe:200 $\mathrm{nM} \mathrm{PO}_{4}{ }^{3-}$ in Patch 1 and Patch 2, respectively, compared to background concentrations of approximately $10 \mathrm{nM} \mathrm{PO}_{4}{ }^{3-}$ and $0.3 \mathrm{nM} \mathrm{Fe}$ (Rees et al. 2007). Whereas total primary production showed only small deviations from the unamended control site, rates of $\mathrm{PO}_{4}{ }^{3-}$ uptake and $\mathrm{N}_{2}$ fixation in the 2 experimental treatments increased 6 -fold and 4.5-fold, respectively (suggesting that only a small fraction of the photoautotrophic assemblage, probably composed of diazotrophs, responded initially to the nutrient enrichments); the dominant diazotroph in this habitat was a unicellular cyanobacterium (Rees et al. 2007). Particulate matter export to the deep sea was not measured during either the CYCLOPS or FeeP, so the potential impact on $\mathrm{CO}_{2}$ sequestration from these fertilization experiments and the enhanced $\mathrm{N}_{2}$ fixation they triggered is currently unknown.

\section{CONTROLLED UPWELLING}

Lovelock \& Rapley (2007) recently suggested that the purposeful delivery of deep-water nutrients to the euphotic zone (i.e. artificial or controlled upwelling) might enhance primary and export production and thereby constitute an effective mechanism for $\mathrm{CO}_{2}$ se-
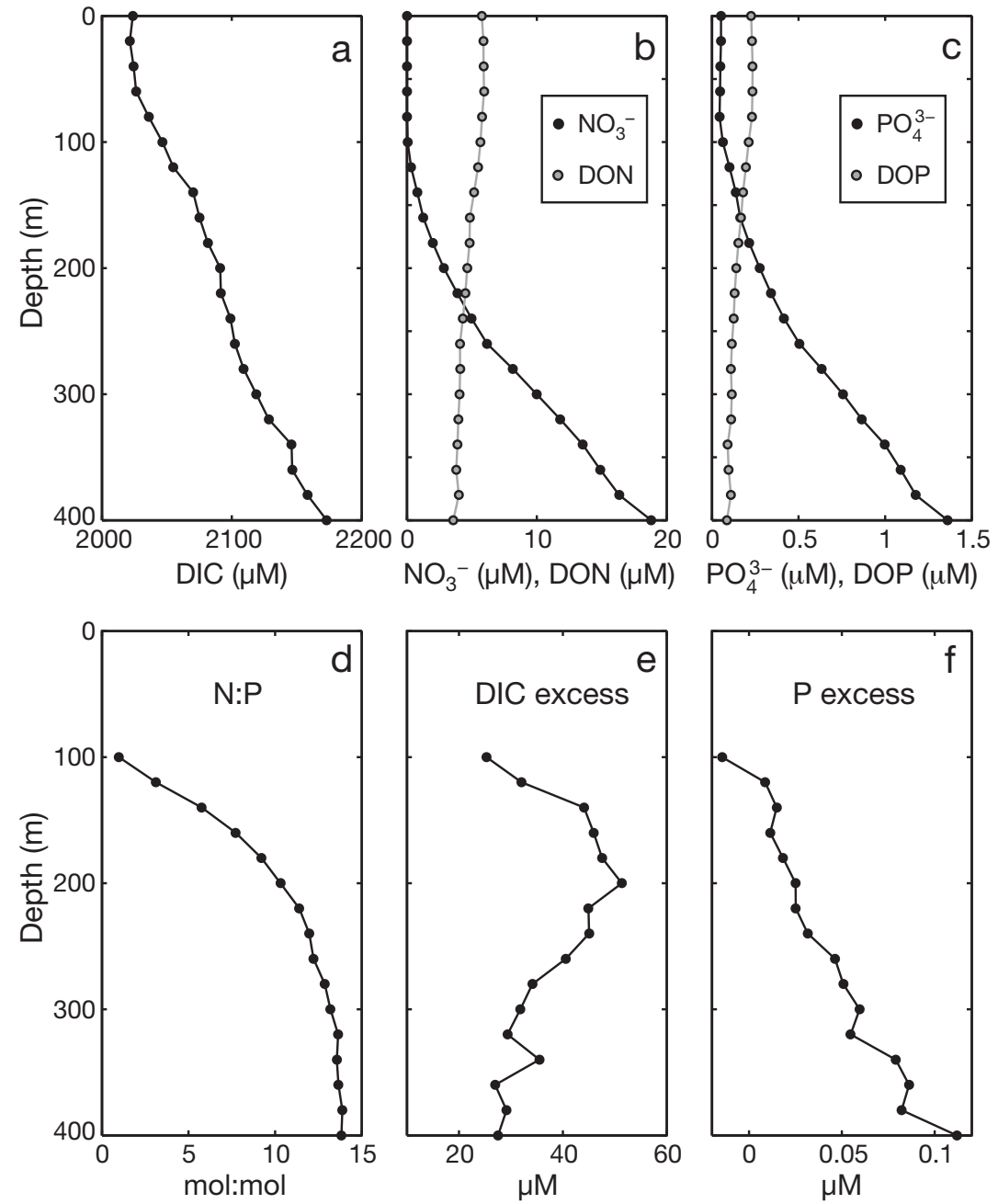

Fig. 2. Vertical profiles (a-c) of dissolved inorganic carbon (DIC) and dissolved nitrate and phosphate $\left(\mathrm{NO}_{3}{ }^{-}\right.$and $\mathrm{PO}_{4}{ }^{3-}$, respectively) and dissolved organic nitrogen and phosphorus (DON and DOP, respectively) concentrations for the upper $400 \mathrm{~m}$ at Station ALOHA. (d-f) $\mathrm{NO}_{3}{ }^{-}: \mathrm{PO}_{4}{ }^{3-}(\mathrm{N}: \mathrm{P})$ molar ratios and excess DIC and excess P in the upper $400 \mathrm{~m}$ at Station ALOHA. Excess DIC and $\mathrm{PO}_{4}{ }^{3-}$ were calculated as described in Table 1, and represent the DIC and P concentrations that would remain if the $\mathrm{NO}_{3}{ }^{-}$from each reference depth were assimilated into organic matter with a Redfield stoichiometry $\left(\mathrm{C}_{106}: \mathrm{N}_{16}: \mathrm{P}_{1}\right)$. All values shown are based on the long-term climatology (1989-2006) for this low-nitrate, lowchlorophyll (LNLC) station (data available at http://hahana.soest.hawaii.edu) 
However, since the ratio of $\mathrm{DIC}: \mathrm{NO}_{3}{ }^{-}: \mathrm{PO}_{4}{ }^{3-}(\mathrm{C}: \mathrm{N}: \mathrm{P})$ in deep-sea waters is variable, the ecological consequences of a controlled upwelling experiment is predicted to be site- and depth-specific and, for some regions, seasonally dependent due to local variations in solar irradiance, surface mixed layer depth and temperature.

Based on our current understanding of marine microbial biogeochemistry, if deep waters are introduced to the surface ocean, a phytoplankton bloom (i.e. enhancement in the growth rate of one or more species leading to an increase in biomass; Richardson 1997) will result, following the stratification of the upper water column. It is well known that a sudden pulse of inorganic nutrients into the euphotic zone selects for rapidly growing, mostly eukaryotic phyto- plankton (especially diatoms). Although the background microbial loop continues to be active, it is overprinted by larger phytoplankton species that can respond quickly to the introduction of allochthonous nutrients and have few predators, at least initially, allowing accumulation and subsequent sedimentation out of the euphotic zone (Karl 1999, Cullen et al. 2002). The nature of the upwelling nutrient supply, for example whether it is continuous or pulsed, can also influence the dynamical behavior and trophic structure of the resultant community (Wiegert \& Penas-Lado 1995) and ultimately affect the C:N:P stoichiometry of the organic matter that is exported from the system. For any controlled upwelling experiment, the nutrient supply rate is a key design criterion.

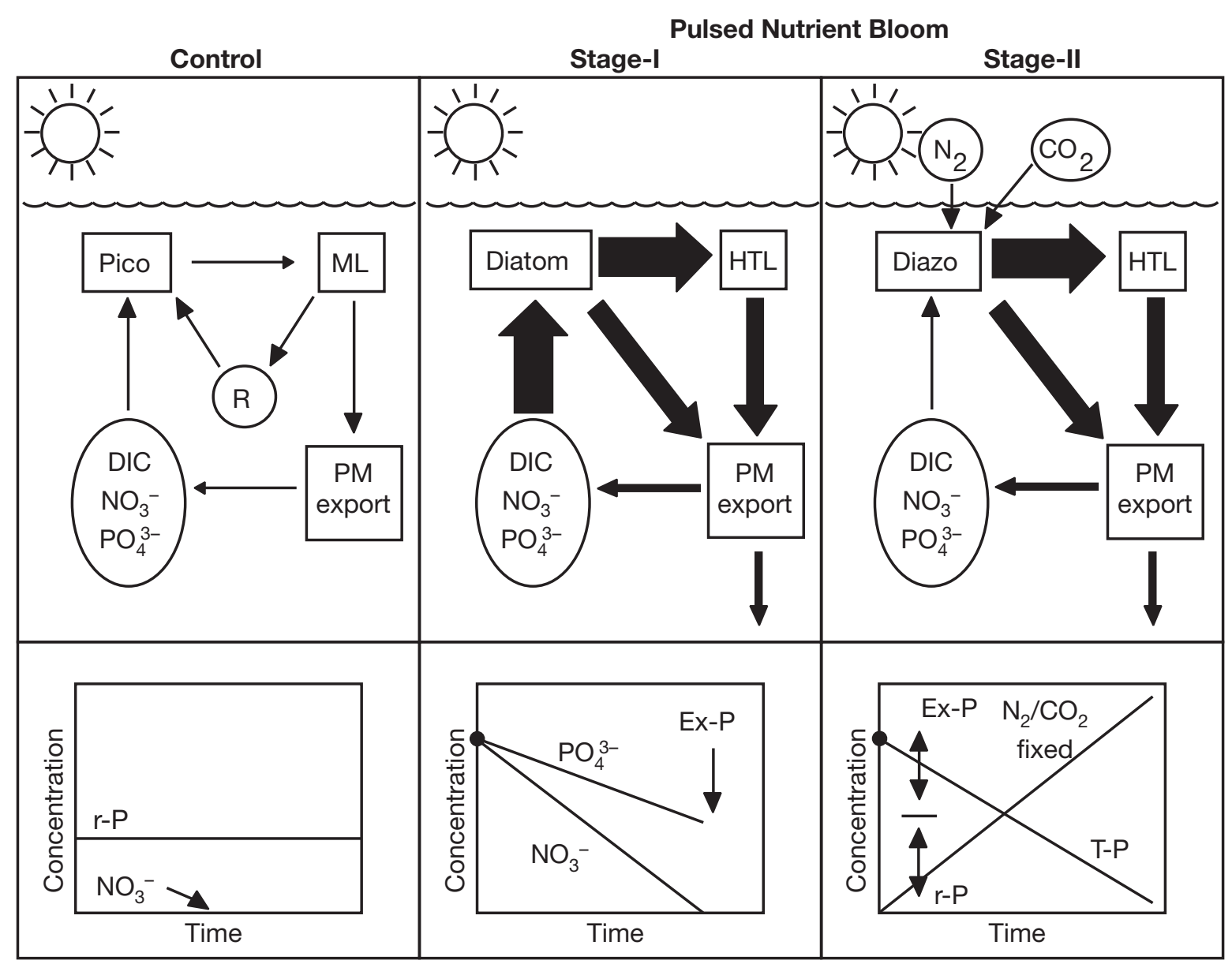

Fig. 3. Hypothesized ecosystem processes following a controlled nutrient upwelling event: (left) unamended control region, with low background nutrient fluxes from below the euphotic zone, a remineralization (R)-intensive picophytoplankton-based (Pico) microbial loop (ML) and low rates of particulate matter (PM) export mostly remineralized back to inorganic nutrients (dissolved inorganic carbon [DIC], $\mathrm{NO}_{3}{ }^{-}$and $\mathrm{PO}_{4}{ }^{3-}$ ) in the upper mesopelagic zone (plot at the bottom depicts the hypothesized time-dependent changes in $\mathrm{NO}_{3}{ }^{-}$and residual $\mathrm{P}[\mathrm{r}-\mathrm{P}]$ ); (center) Stage I of the inorganic nutrient (DIC, $\mathrm{NO}_{3}{ }^{-}, \mathrm{PO}_{4}{ }^{3-}$ ) supported phytoplankton bloom of diatoms $\left(\sim \mathrm{C}_{106}: \mathrm{N}_{16}: \mathrm{P}_{1}\right)$ that exports additional PM partly by the combination of aggregation/sinking of intact cells and coupled higher trophic level (HTL) processes - based on the PM composition and sinking rates, a larger portion penetrates deeper into the water column facilitating long-term $\mathrm{CO}_{2}$ sequestration (plot at the bottom depicts the excess $\mathrm{P}$ [Ex-P] that remains after all the $\mathrm{NO}_{3}{ }^{-}$in the upwelled water has been assimilated); (right) total P (T-P Ex-P + r-P) supports the Stage II $\mathrm{N}_{2}$-based bloom of diazotrophs $\left(\sim \mathrm{C}_{331}: \mathrm{N}_{50}: \mathrm{P}_{1}\right)$ that assimilate $\mathrm{N}_{2}$ and $\mathrm{CO}_{2}$ and enhance the potential for $\mathrm{CO}_{2}$ sequestration as described in section 'Controlled upwelling' and in Table 1 
Based on field observations and experiments conducted at Station ALOHA $\left(22^{\circ} 45^{\prime} \mathrm{N}, 158^{\circ} \mathrm{W}\right)$ over the past 2 decades (e.g. Karl 1999) and recent results of shipboard experiments that simulate upwelling (McAndrew et al. 2007), we hypothesize that controlled upwelling of Fe-replete deep water containing excess $P$ (low $\mathrm{NO}_{3}{ }^{-}: \mathrm{PO}_{4}{ }^{3-}$ ) into the surface layers of the NPSG (a LNLC ecosystem) will lead to a 2-staged phytoplankton bloom (Fig. 3). Stage I is characterized by an immediate (hours to a few days) bloom of rapidly growing phytoplankton (typically diatoms; McAndrew et al. 2007) that assimilate $\mathrm{DIC}, \mathrm{NO}_{3}{ }^{-}$and $\mathrm{PO}_{4}{ }^{3-}$, and trigger the export of particulate organic matter with a predictable stoichiometry of $\mathrm{C}_{106}: \mathrm{N}_{16}: \mathrm{P}_{1}$ (so-called Redfield ratio), leaving excess $\mathrm{P}$ (and possibly excess DIC, depending on the DIC: $\mathrm{PO}_{4}{ }^{3-}$ ratio and concentration of $\mathrm{NO}_{3}{ }^{-}$in the upwelled waters) in its wake. The excess $\mathrm{PO}_{4}{ }^{3-}$ supplements the $\mathrm{r}-\mathrm{P}$, if any, already present in the surface waters, leading to a $\mathrm{N}_{2}$-fixing cyanobacterial bloom, as described above. This Stage II bloom imports new N through the process of $\mathrm{N}_{2}$ fixation, resulting in an enhanced sequestration of $\mathrm{CO}_{2}$ over and above the DIC that was initially introduced to the euphotic zone by the upwelling event, depending upon the DIC: $\mathrm{PO}_{4}{ }^{3-}$ ratio of the upwelled water and the C:P ratio of the exported organic matter (Fig. 3). The production of excess bioavailable $\mathrm{N}$ in the form of ammonium and dissolved organic nitrogen, a feature that is characteristic of diazotroph growth in general (Capone et al. 1994, Mulholland et al. 2004), will ensure the efficient scavenging of total $\mathrm{P}$ and lead to efficient carbon export, provided adequate light and Fe are both available. In situ observations of summer blooms dominated by diazotrophs in LCLN regions lend support to this hypothesis (Karl et al. 1992, Uz 2007, Dore et al. 2008).

The efficacy of $\mathrm{C}$ sequestration by $\mathrm{N}_{2}$-based new production is enhanced by growth in P-limited environments. Diazotrophic growth is characterized by variable C:P stoichiometry in both the laboratory and the field, with C:P ratios ranging from 100 to 1000, with significantly reduced $\mathrm{P}$ cell quota under conditions of P stress (Karl et al. 1992, White et al. 2006). Even non-diazotrophic phytoplankton exhibit a P-sparing effect and synthesize new cell materials with elevated C:P when $\mathrm{P}$ becomes limiting (Bertilsson et al. 2003, Van Mooy et al. 2006). Consequently, this altered, C-enriched stoichiometry enhances the P-specific $\mathrm{CO}_{2}$ sequestration potential of the Stage II $\mathrm{N}_{2}$-based bloom. Characterizing and understanding the processes governing the plasticity of elemental coupling (stoichiometry) in the biologically mediated production, remineralization and export of organic matter in these oligotrophic environments is critical if we are to assess potential $\mathrm{CO}_{2}$ sequestration by these ecosystems. From a biogeochemical perspective, there is nothing as fundamental as the elemental stoichiometry defined by biological systems through the coupling, storage and transport of nutrients.

\section{N$_{2}$ FIXATION CASE STUDY: STATION ALOHA}

The key to net $\mathrm{CO}_{2}$ sequestration by controlled upwelling is the selection of an appropriate source water (geographic location and depth). Station ALOHA is the deep-water benchmark site of the Hawaii Ocean Timeseries (HOT) program, where systematic observations of microbial biogeochemistry have been made since October 1988 (Karl \& Lukas 1996). It is a typical LNLC, moderate r-P (30 to $50 \mathrm{nM}$ ) habitat with non-limiting total dissolved Fe concentrations (0.2 to $0.8 \mathrm{nM}$; Boyle et al. 2005). Assuming that a significant portion of the $\mathrm{Fe}$ is bioavailable, the well-illuminated surface waters of Station ALOHA should be a favorable habitat for the proliferation of $\mathrm{N}_{2}$-fixing microorganisms. This prediction has been confirmed by direct measurements, including: (1) the abundances of the putative diazotrophs, (2) quantitative estimation of nifH gene abundances and expression, (3) ${ }^{15} \mathrm{~N}_{2}$ tracer assimilation experiments, (4) $\mathrm{N}$ isotopic abundance of suspended and exported particulate matter, and (5) C:N:P stoichiometrics of dissolved and particulate matter pools (Karl et al. 1992, Letelier \& Karl 1996, Karl et al. 1997, Church et al. 2005a,b). An intriguing observation from this ongoing $20 \mathrm{yr}$ program is the reduction in r-P in the upper $60 \mathrm{~m}$ of Station ALOHA from a depth-integrated inventory of approximately $5 \mathrm{mmol} \mathrm{P} \mathrm{m}^{-2}$ in 1989 to $<2 \mathrm{mmol} \mathrm{P} \mathrm{m}^{-2}$ in 2005 (Fig. 4). Within this long-term trend we also observe strong sub-seasonal variability in 0 to $60 \mathrm{~m}$ depth-integrated $\mathrm{P}$ with the lowest values observed following summer blooms of diazotrophs (White et al. 2007). Between 1989 and 2005 the total pool of particulate phosphorus (PP) has also decreased significantly, and the C:P and N:P ratios of the suspended particulate matter have systematically increased to values well in excess of the Redfield ratios that were observed 20 yr ago (Fig. 4). This longterm, decadal process can be viewed as a 'slow motion' bloom of $\mathrm{N}_{2}$-fixing microorganisms controlled by some process other than $\mathrm{P}$ availability, possibly grazing, viral lysis, the bioavailability of $\mathrm{Fe}$, or increased water column stratification (Karl 2007b). Top-down control by grazing or viral lysis is very likely in remineralizationintensive habitats like Station ALOHA. Bottom-up biomass control by Fe, or any other growth-limiting substrate, could occur independently or in conjunction with top-down control.

Based on our current understanding of this oligotrophic habitat, we predict that the addition of $\mathrm{Fe}$ to waters surrounding Station ALOHA may trigger a diazotroph bloom; if both $\mathrm{Fe}$ and $\mathrm{P}$ are added, the 


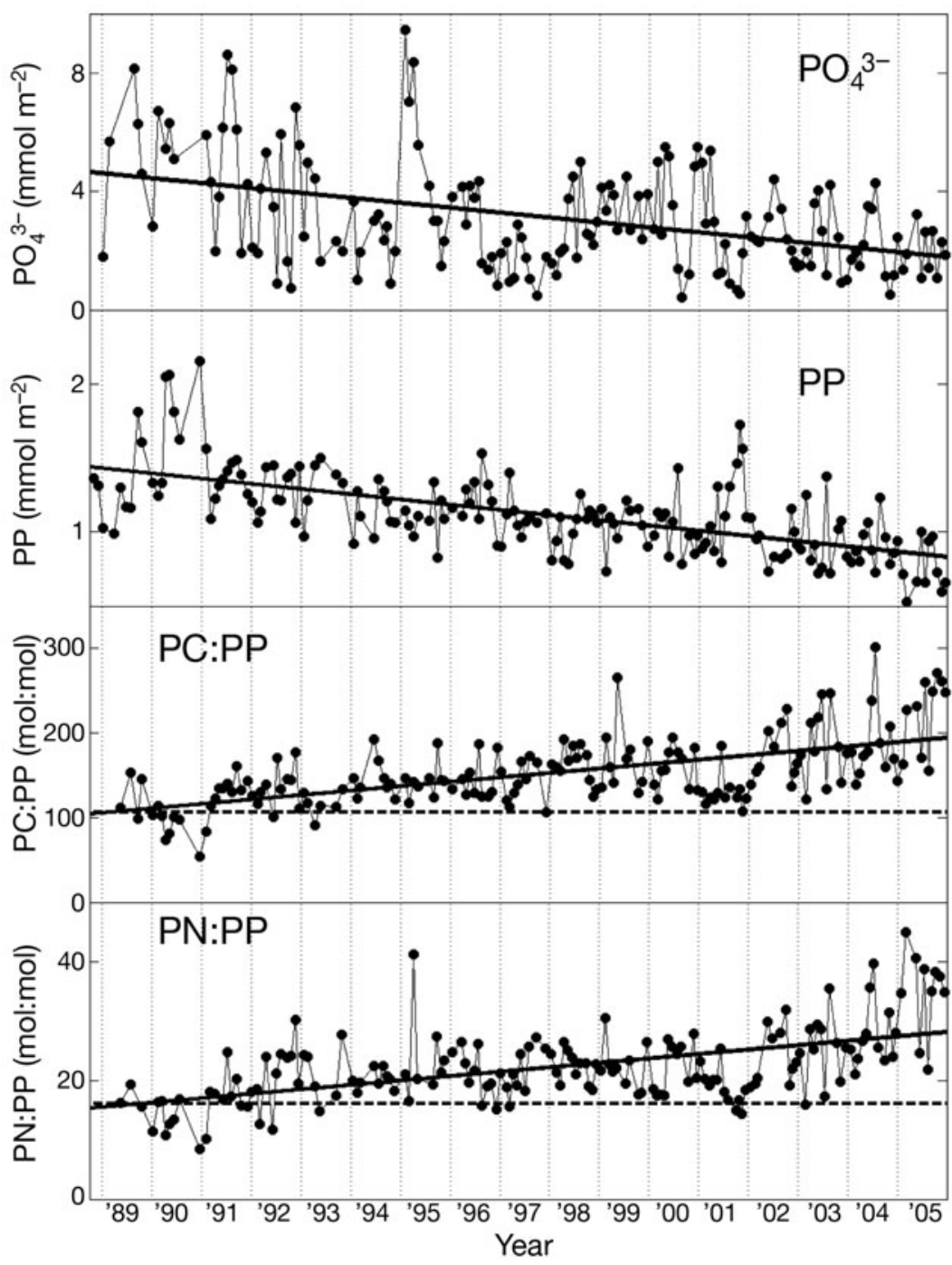

Fig. 4. Station ALOHA phosphorus pool dynamics. Shown is the 17 yr time-series of $\mathrm{PO}_{4}{ }^{3-}$ integrated over the upper $60 \mathrm{~m}$ of the water column, particulate phosphorus (PP) integrated over the upper $75 \mathrm{~m}$ of the water column, and the average $(0-75 \mathrm{~m}) \mathrm{C}: \mathrm{P}$ and $\mathrm{N}: \mathrm{P}$ ratios of the particulate matter pools (PC:PP and PN:PP, respectively). Solid lines represent the best-fit linear regression analyses for each data set and the dashed line in the PC:PP and PN:PP plots is the global average stoichiometry $\left(\mathrm{C}_{106}: \mathrm{N}_{16}: \mathrm{P}_{1}\right)$ for marine particulate matter. The decreasing concentrations of SRP and PP, and increasing PC:PP and PN:PP ratios are all predicted from the hypothesized enhancement of $\mathrm{N}_{2}$ fixation at Station ALOHA over the past 2 decades (Karl 2007a)

probability of a $\mathrm{N}_{2}$-based bloom is even greater. However, it is obvious from the field observations at Station ALOHA that this seascape is not in biogeochemical steady state, but rather, supports a dynamic and timevariable ecosystem.

An important characteristic of the vertical nutrient structure at Station ALOHA is the low $\mathrm{NO}_{3}{ }^{-}: \mathrm{PO}_{4}{ }^{3-}$ ratio in the upper $200 \mathrm{~m}$ of the water column (Fig. 2). Consequently, as deep waters are introduced into the near surface, whether by natural eddy-diffusion processes or by controlled upwelling, $\mathrm{NO}_{3}^{-}$will be rapidly assimi- lated by phytoplankton along with DIC and $\mathrm{PO}_{4}{ }^{3-}$ in relative proportions that approximate the Redfield ratio of $\mathrm{C}_{106}: \mathrm{N}_{16}: \mathrm{P}_{1}$, the stoichiometry of average marine particulate matter (Stage I bloom; Figs. 3 \& 5). Depending upon the depth of origin of the upwelled waters (controlled by experimental design) the complete assimilation of $\mathrm{NO}_{3}{ }^{-}$will leave behind excess $\mathrm{PO}_{4}{ }^{3-}$ to supplement the $\mathrm{r}-\mathrm{P}$ already present in the surface waters (Fig. 2, Table 1). Fe is also introduced as water is upwelled. However, both the biological requirements for $\mathrm{Fe}$ and the availability of the Fe upwelled are difficult to estimate, given the large range of Fe requirements reported in the literature (Sunda 1991) and the observation at Station ALOHA that a significant proportion of 'dissolved' Fe may be chelated with Fe-binding organic ligands (Wu et al. 2001). Nevertheless, the recurrent observation of diazotrophic summer blooms at Station ALOHA, followed by a significant reduction in r-P (White et al. 2007), suggests that Fe does not limit $\mathrm{N}_{2}$-fixation at this site; most likely, there may be a temporal oscillation between Fe and P nutrient limitation, or co-limitation (Grabowski et al. in press).

The upwelled waters at Station ALOHA contain excess DIC (relative to $\mathrm{NO}_{3}{ }^{-}$, assuming Redfield stoichiometry) and variable excess DIC: excess P ratios depending on water depth (Fig. 2, Table 1). If the partial pressure of $\mathrm{CO}_{2}$ in the surface waters is at or above equilibrium with the atmosphere, the addition of excess DIC may result in an ocean-to-atmosphere transfer of $\mathrm{CO}_{2}$. However, at Station ALOHA, the surface waters are nearly always undersaturated with respect to atmospheric $\mathrm{CO}_{2}$ (although the extent of undersaturation appears to have decreased between 1990 and 2000; Dore et al. 2003), so the excess DIC in upwelled waters (up to approximately 20 to $30 \mu \mathrm{M}$ ) will be retained unless the surface ocean warms. Furthermore, recent laboratory studies of $\mathrm{N}_{2}$ fixation as a function of $\mathrm{pCO}_{2}$ suggest that Trichodesmium spp. displays $\mathrm{CO}_{2}$ limitation under presentday conditions (Hutchins et al. 2007). Consequently, an increase in surface $\mathrm{pCO}_{2}$ by controlled upwelling may even stimulate nitrogen fixation in a well-stratified water column. 

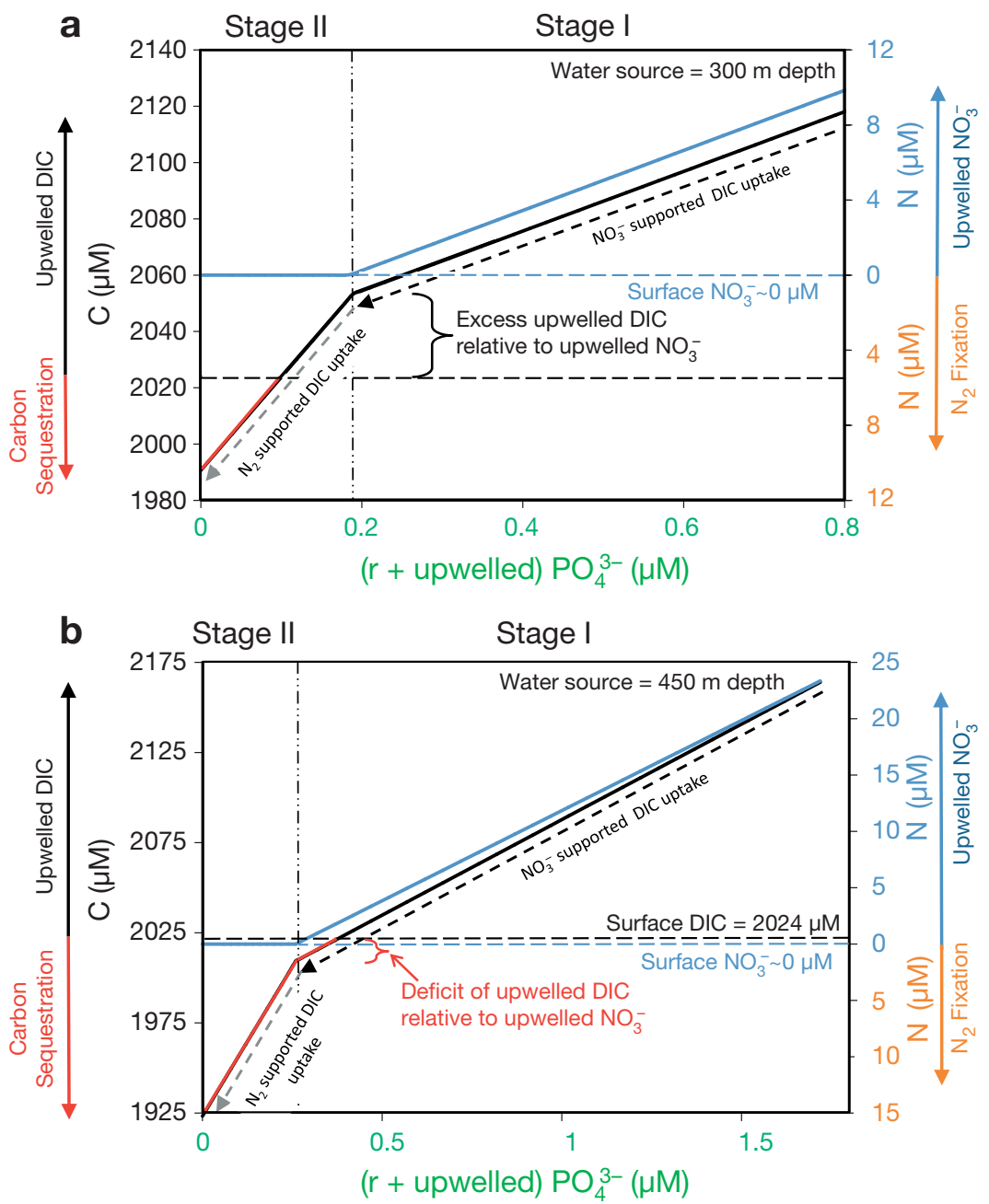

Fig. 5. Hypothetical evolution of DIC and $\mathrm{NO}_{3}{ }^{-}$concentrations as a function of total $\mathrm{PO}_{4}{ }^{3-}$ concentration following the upwelling of (a) $300 \mathrm{~m}$ and (b) $450 \mathrm{~m}$ deep water into the upper euphotic zone at Station ALOHA. The increase of DIC (black arrow along left axis) and $\mathrm{NO}_{3}{ }^{-}$(blue arrow along white axis), relative to background surface ocean concentrations (horizontal dashed lines) will support a $\mathrm{NO}_{3}{ }^{-}$based bloom characterized by Redfield stoichiometry (Stage I bloom), reducing DIC and $\mathrm{PO}_{4}{ }^{3-}$ until $\mathrm{NO}_{3}{ }^{-}$is depleted. Following $\mathrm{NO}_{3}{ }^{-}$depletion, the remaining $\mathrm{PO}_{4}{ }^{3-}$ should support a $\mathrm{N}_{2}$ based bloom (Stage II bloom and brown right axis) with an enhanced $\mathrm{C}: \mathrm{P}$ and $\mathrm{N}: \mathrm{P}$ stoichiometry, leading to the net sequestration of DIC in surface waters (red line within the graph). The vertical dash-dotted line marks the transition between Stage I and Stage II of the bloom. Note that while the $300 \mathrm{~m}$ upwelled water has excess DIC relative to $\mathrm{NO}_{3}{ }^{-}$, the water from $450 \mathrm{~m}$ has a deficit of DIC relative to $\mathrm{NO}_{3}^{-}$leading to the removal of DIC even in the absence of $\mathrm{N}_{2}$ fixation

Regardless of excess DIC concentration, excess P in the upwelled waters would most likely control the dynamics of $\mathrm{N}_{2}$-based new production and carbon export (Figs. $2 \& 3$, Table 1). Therefore, the key factors for determining $\mathrm{CO}_{2}$ sequestration via $\mathrm{N}_{2}$-fixation in subtropical oligotrophic regions based on the longterm observations at Station ALOHA are (1) the excess DIC:excess $\mathrm{P}$ ratio in the upwelled waters, (2) the r-P concentration, (3) the saturation state of the surface ocean with respect to atmospheric $\mathrm{CO}_{2}$, (4) the stratification of the upper water column, and (5) the C:P ratio of exported organic matter. The relative excess of $\mathrm{P}$ in upwelled waters (Fig. 2, Table 1) would ensure a significant net sequestration of $\mathrm{CO}_{2}$ as long as $\mathrm{N}_{2}$ based production and remineralization of the organic matter are uncoupled in time and with depth. Furthermore, the surface waters at Station ALOHA always contain r-P (although the amount appears to be decreasing over the past 2 decades), so the excess $P$ delivered via upwelling would supplement the $\mathrm{r}-\mathrm{P}$, further enhancing $\mathrm{N}_{2}$ based production and export, especially following the initial Redfield bloom, until either P or Fe becomes limiting for diazotrophic growth.

Based on well-constrained environmental observations at Station ALOHA (http://hahana.soest.hawaii.edu), we can provide estimates of the $\mathrm{CO}_{2}$ sequestration potential following controlled upwelling from a variety of target depths using reasonable biogeochemical assumptions (Table 1). The derived values reported are $\mathrm{CO}_{2}$ sequestered $\mathrm{m}^{-3}$ of upwelled water, provided sufficient $\mathrm{Fe}$ is available. There is an important tradeoff in the selection of the optimal source water between the $\mathrm{NO}_{3}{ }^{-}: \mathrm{PO}_{4}{ }^{3-}$ and the excess DIC:excess $\mathrm{P}$ ratios (Table 1). If our assumptions and calculations are reasonable, then the delivery of deeper waters $(>300 \mathrm{~m})$ would appear to be more efficient at removing $\mathrm{CO}_{2}$ than delivery of waters from immediately below the euphotic zone (e.g. 140 to $200 \mathrm{~m})$, where dissolved $\mathrm{Fe}$ is at a minimum (Johnson et al. 1997) and the excess DIC:excess $\mathrm{P}$ ratio is at maximum. Zonal and meridional transects in the region surrounding Station ALOHA, as well as long-term observations at this benchmark confirm that low $\mathrm{NO}_{3}{ }^{-}: \mathrm{PO}_{4}{ }^{3-}$ concentration ratios in subeuphotic-zone water depths are a characteristic feature of the NPSG (Fig. 6); hence, it is likely that the calculations from Station ALOHA might be appropriate for the regional gyre scale. However, over extended temporal scales (decades to centuries) of continuous upwelling, the export and remineralization of particulate organic matter with elevated C:P 
Table 1. Nutrient balance and net $\mathrm{CO}_{2}$ sequestration potential for precision upwelled waters at Station ALOHA. DIC: dissolved inorganic carbon; r-P: residual phosphorus

\begin{tabular}{|c|c|c|c|c|c|c|c|c|c|}
\hline \multirow{3}{*}{$\begin{array}{l}\text { Source } \\
\text { Water } \\
(\mathrm{m})\end{array}$} & \multirow{2}{*}{\multicolumn{3}{|c|}{$\begin{array}{c}\text { Total nutrient } \\
\text { concentration }(\mu \mathrm{M})\end{array}$}} & \multicolumn{3}{|c|}{ Excess nutrient concentration ${ }^{\mathrm{a}}$} & \multirow{3}{*}{$\begin{array}{c}\text { Total P } \\
\text { (excess } \\
\text { plus r-P, } \\
\mu \mathrm{M})\end{array}$} & \multirow{3}{*}{$\begin{array}{c}\text { Total } N_{2} \\
\text { fixation }^{b} \\
(\mu \mathrm{M})\end{array}$} & \multirow{3}{*}{$\begin{array}{c}\text { Net C } \\
\text { sequestered } \\
\left(\text { mmol C m }{ }^{-3}\right. \\
\text { upwelled })^{\mathrm{c}}\end{array}$} \\
\hline & & & & DIC & P & DIC:P & & & \\
\hline & DIC & $\mathrm{NO}_{3}^{-}$ & $\mathrm{PO}_{4}^{3-}$ & $(\mu \mathrm{M})$ & $(\mu \mathrm{M})$ & (mol:mol) & & & \\
\hline 100 & 2046 & 0.06 & 0.062 & 22 & 0.058 & $371: 1$ & 0.111 & 5.6 & 15.2 \\
\hline 120 & 2055 & 0.32 & 0.101 & 29 & 0.081 & $357: 1$ & 0.134 & 6.7 & 15.5 \\
\hline 140 & 2070 & 0.79 & 0.137 & 41 & 0.088 & $465: 1$ & 0.141 & 7.0 & 5.8 \\
\hline 160 & 2075 & 1.26 & 0.163 & 43 & 0.084 & 512:1 & 0.137 & 6.8 & 2.5 \\
\hline 180 & 2082 & 1.98 & 0.215 & 45 & 0.091 & 492:1 & 0.144 & 7.2 & 2.9 \\
\hline 200 & 2091 & 2.84 & 0.276 & 48 & 0.099 & 489:1 & 0.152 & 7.6 & 2.0 \\
\hline 250 & 2100 & 5.58 & 0.461 & 39 & 0.112 & $348: 1$ & 0.165 & 8.3 & 15.7 \\
\hline 300 & 2119 & 9.99 & 0.757 & 29 & 0.133 & $217: 1$ & 0.186 & 9.3 & 32.7 \\
\hline 350 & 2146 & 14.22 & 1.044 & 28 & 0.155 & 179:1 & 0.208 & 10.4 & 41.2 \\
\hline 400 & 2173 & 18.82 & 1.361 & 24 & 0.185 & 132:1 & 0.238 & 11.9 & 54.5 \\
\hline 450 & 2164 & 23.35 & 1.667 & -15 & 0.208 & $-71: 1$ & 0.261 & 13.0 & 101.1 \\
\hline 500 & 2199 & 28.00 & 2.033 & -11 & 0.283 & $-37: 1$ & 0.336 & 16.8 & 121.8 \\
\hline 750 & 2313 & 40.90 & 2.985 & 18 & 0.429 & 42 & 0.482 & 24.1 & 141.5 \\
\hline 1000 & 2337 & 41.58 & 3.006 & 38 & 0.407 & 92 & 0.460 & 23.0 & 114.9 \\
\hline
\end{tabular}

and $\mathrm{N}: \mathrm{P}$ ratios may eventually alter the nutrient ratios of subeuphotic zone waters, thereby reducing the efficacy of controlled upwelling as a method of net $\mathrm{CO}_{2}$ sequestration (Karl 2002).

The primary uncertainties in these first-order calculations of $\mathrm{CO}_{2}$ sequestration potential are: (1) the role of dissolved organic N and P (DON and DOP, respectively) in supporting bloom dynamics or, for DOP, as a supplemental reservoir of $\mathrm{r}-\mathrm{P}$ to further enhance $\mathrm{N}_{2} / \mathrm{CO}_{2}$ fixed, (2) the type of diazotroph community that is established during Stage II of the upwellinginduced bloom and (3) the C:N:P stoichiometry of the organic matter that is produced and exported. With respect to the role of DON/DOP, it is important to emphasize that these organic nutrient pools are the dominant reservoirs of $\mathrm{N}$ and $\mathrm{P}$ in surface waters at Station ALOHA (Fig. 2). However, their bioavailability, especially for DON, and the N:P ratio of the bioavailable fraction are not known or even well-constrained at present. Nevertheless, it has been demonstrated that approximately $50 \%$ of the total $\mathrm{P}$ assimilated in the surface waters at Station ALOHA is derived from DOP (Björkman \& Karl 2003), so at least a fraction of the fairly large DOP pool in surface waters is also expected to support net $\mathrm{CO}_{2}$ uptake and a concomitant carbon export to the deep sea.

There are at least 3 fundamentally different groups of diazotrophs at Station ALOHA: (1) small, free-living unicellular cyanobacteria (Crocosphaera-like), large filamentous and colonial morphologies of the cyanobacteria Trichodesmium spp. and (3) Richelialike cyanobacteria living as ecto- and endosymbionts with several species of large, aggregate-forming diatoms (e.g., Rhizosolenia spp., Hemiaulus hauckii). The $\mathrm{N}_{2}$ and $\mathrm{CO}_{2}$ fixed by each of these groups will have a different impact on export, despite the fact that all belong to the same diazotroph guild. Finally, the C:P ratio of newly synthesized and exported organic matter is a critical consideration for $\mathrm{CO}_{2}$ sequestration. As mentioned previously, diazotrophs, as well as many eukaryotic phytoplankton, exhibit a P-sparing effect (a reduction in $\mathrm{P}$ cell quota) under conditions of $\mathrm{P}$ limitation, thereby increasing the $\mathrm{P}$-specific sequestration of $\mathrm{CO}_{2}$.

The best proof of this concept is to 'study nature, not books,' as Louis Agassiz advised many years ago. $\mathrm{N}_{2}$ based, high C:P export/efficient $\mathrm{CO}_{2}$ sequestration Stage II phytoplankton blooms occur at Station ALOHA, usually in summer when the water column is well stratified (White et al. 2007, Dore et al. 2008, Fong et al. 2008). While the mechanisms that establish and sustain the periodic greening of the oligotrophic oceanic desert are not yet known, nutrient loading, especially of $\mathrm{Fe}$ and $\mathrm{PO}_{4}{ }^{3-}$, either from above (dust deposition) or below, is the most likely cause (Dore et al. 2008). However, the dynamical coupling between nutrient delivery and excess carbon export is not well constrained either for Station ALOHA or for any other 

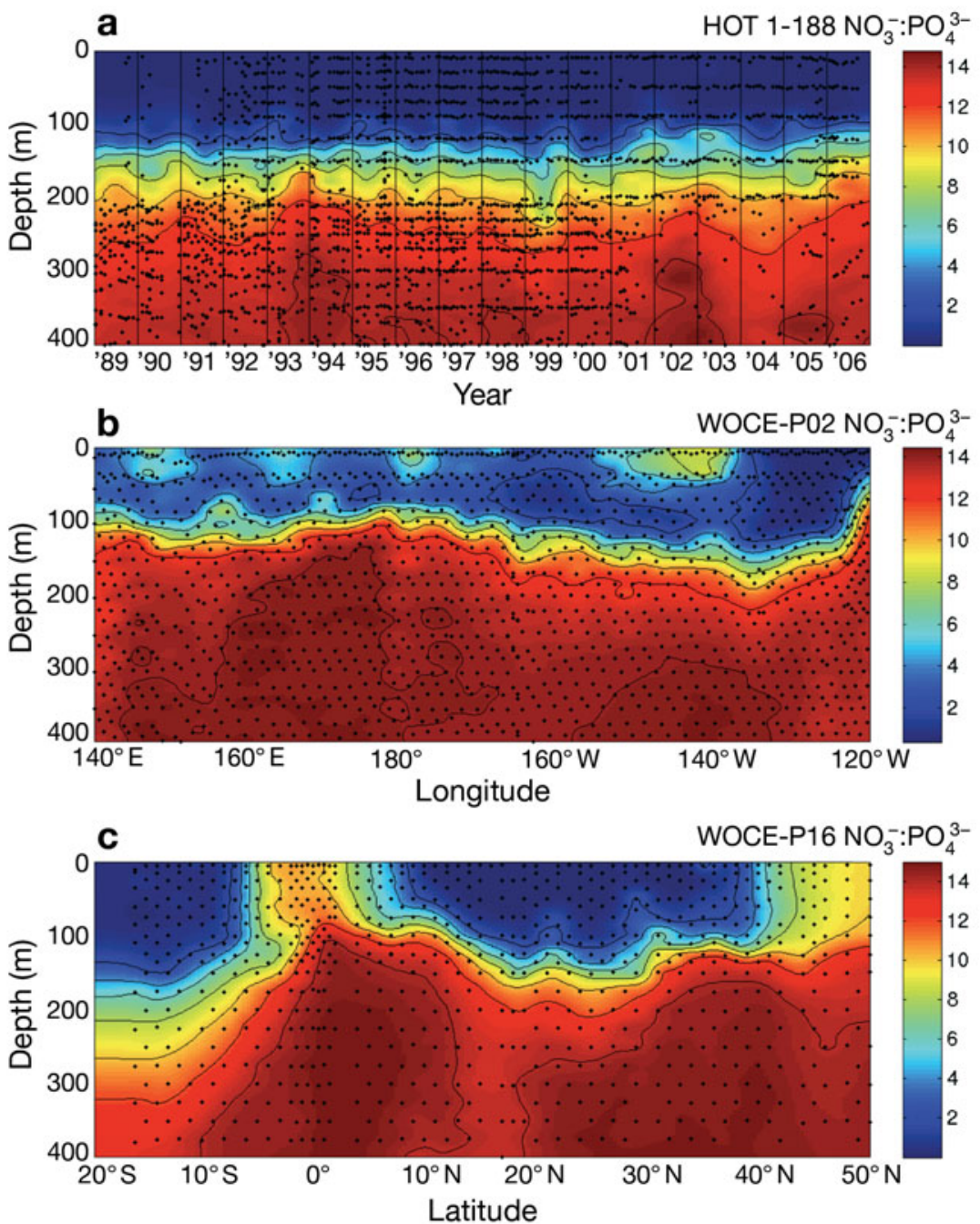

Fig. 6. Contour plots of $\mathrm{NO}_{3}{ }^{-}: \mathrm{PO}_{4}{ }^{3-}$ for the North Pacific Ocean: (a) time-series of $\mathrm{NO}_{3}{ }^{-}: \mathrm{PO}_{4}{ }^{3-}$ ratio at Station ALOHA for 1989-2006; (b) meridional section along $30^{\circ} \mathrm{N}$, World Ocean Circulation Experiment (WOCE) line P02; (c) section along $150^{\circ} \mathrm{W}$, WOCE line P16. Hawaii ocean time-series (HOT) data from http://hahana. soest.hawaii.edu and WOCE data from http://WOCE.nodc.noaa.gov/wdiu

tential secondary impacts might include the production of nitrous oxide $\left(\mathrm{N}_{2} \mathrm{O}\right)$ via coupled $\mathrm{N}_{2}$ fixation-nitrification $\left(\mathrm{N}_{2} \rightarrow \mathrm{NH}_{4}^{+} \rightarrow \mathrm{N}_{2} \mathrm{O}\right)$ and the aerobic production of methane $\left(\mathrm{CH}_{4}\right)$ from enhanced cycling of methylphosphonate, a likely component of the DOP pool (Karl et al. 2008). Either one of these unintended consequences, or others not yet considered, could negate the impact of $\mathrm{CO}_{2}$ sequestration because both $\mathrm{N}_{2} \mathrm{O}$ and $\mathrm{CH}_{4}$ are potent greenhouse gases. Toxin production by both of the probable bloom-forming algal assemblages, diatoms and diazotrophs, is also possible and may have significant ecological consequences. Well-designed and comprehensive nutrient perturbation experiments that examine all aspects of microbial metabolism likely to be influenced by controlled upwelling, not just the intended consequences, need to be conducted before diazotroph manipulation can be promoted as a potential climate stabilization wedge (Socolow \& Pacala 2006).

Human-induced climate change is already having measurable environmental consequences that need to be addressed by the scientific community. Sitting idle or criticizing those who do take a position on geo-engineering are not good options, in our opinion. The global scale and trajectory of climate change suggest that it may not be possible to address the problem without further affecting natural ecosystems. For this reason, understanding the ecosystem response to human-induced

marine ecosystem. Recently, Rodier \& Le Borgne (2008) proposed a similar nutrient-trigger hypothesis to explain aperiodic blooms of Trichodesmium spp. in coastal waters of New Caledonia. In their study, Trichodesmium spp. blooms followed phosphate and chlorophyll enrichments with a 3 to $7 \mathrm{~d}$ lag, not unlike our hypothesized Stage I/Stage II progression.

\section{FUTURE PROSPECTS}

In promoting natural seascape engineering projects to enhance the efficiency for the ocean's biological carbon pump, one must always be vigilant of unintended consequences (Fuhrman \& Capone 1991, Powell 2008). For the application of $\mathrm{N}_{2}$ fixation-based methods, po- perturbations at a local scale must be a priority in order to develop the bases for risk assessment analyses and to minimize the impacts of geoengineering implementation on a basin-wide or global scale.

Acknowledgments. We thank Philip Boyd for this opportunity to contribute a paper to this Theme Section, David Hutchins and an anonymous reviewer for constructive criticism, and the National Science Foundation and the Gordon and Betty Moore Foundation for their generous funding.

\section{LITERATURE CITED}

Bertilsson S, Berglund O, Karl DM, Chisholm SW (2003) Elemental composition of marine Prochlorococcus and Synechococcus: implications for the ecological stoichiometry of the sea. Limnol Oceanogr 48:1721-1731

Björkman KM, Karl DM (2003) Bioavailability of dissolved 
organic phosphorus in the euphotic zone at Station ALOHA, North Pacific Subtropical Gyre. Limnol Oceanogr 48:1049-1057

Boyle EA, Bergquist BA, Kayser RA, Mahowald N (2005) Iron, manganese, and lead at Hawaii Ocean Time-series station ALOHA: Temporal variability and an intermediate water hydrothermal plume. Geochim Cosmochim Acta 69: 933-952

Capone DG, Ferrier MD, Carpenter EJ (1994) Cycling and release of glutamate and glutamine in colonies of the marine planktonic cyanobacterium, Trichodesmium thiebautii. Appl Environ Microbiol 60:3989-3995

Church MJ, Jenkins BD, Karl DM, Zehr JP (2005a) Vertical distributions of nitrogen-fixing phylotypes at Stn ALOHA in the oligotrophic North Pacific Ocean. Aquat Microb Ecol 38:3-14

Church MJ, Short CM, Jenkins BD, Karl DM, Zehr JP (2005b) Temporal patterns of nitrogenase gene (nifH) expression in the oligotrophic North Pacific Ocean. Appl Environ Microbiol 71:5362-5370

Cullen JJ, Franks PJS, Karl DM, Longhurst A (2002) Physical influences on marine ecosystem dynamics. In: Robinson AR, McCarthy JJ, Rothschild BJ (eds) The sea, Vol 12. John Wiley \& Sons, New York, p 297-336

> Dore JE, Lukas R, Sadler DW, Karl DM (2003) Climate-driven changes to the atmospheric $\mathrm{CO}_{2}$ sink in the subtropical North Pacific Ocean. Nature 424:754-757

Dore JE, Letelier RM, Church MJ, Lukas R, Karl DM (2008) Summer phytoplankton blooms in the oligotrophic North Pacific Subtropical Gyre: historical perspective and recent observations. Prog Oceanogr 76:2-38

Duce RA, Tindale NW (1991) Atmospheric transport of iron and its deposition in the ocean. Limnol Oceanogr 36: 1715-1726

Fong A, Karl DM, Lukas R, Letelier RM, Zehr JP, Church MJ (2008) Nitrogen fixation in an anticyclonic eddy in the oligotrophic North Pacific Ocean. ISME J 2:663-676

Fuhrman JA, Capone DG (1991) Possible biogeochemical consequences of ocean fertilization. Limnol Oceanogr 36: 1951-1959

Grabowski MNW, Church MJ, Karl DM (in press) Nitrogen fixation rates and controls at Stn ALOHA. Aquat Microb Ecol

Ho TY, Quigg A, Finkel ZV, Milligan AJ, Wyman K, Falkowski PG, Morel FMM (2003) The elemental composition of some marine phytoplankton. J Phycol 39:1145-1159

Hutchins DA, Fu FX, Zhang Y, Warner ME and others (2007) $\mathrm{CO}_{2}$ control of Trichodesmium $\mathrm{N}_{2}$ fixation, photosynthesis, growth rates, and elemental ratios: implications for past, present, and future ocean biogeochemistry. Limnol Oceanogr 52: 1293-1304

Isaacs JD, Castel D, Wick GL (1976) Utilization of the energy in ocean waves. Ocean 3:175-187

> Jickells TD, An ZS, Andersen KK, Baker AA and others (2005) Global iron connections between desert dust, ocean biogeochemistry, and climate. Science 308:67-71

> Johnson KS, Gordon RM, Coale KH (1997) What controls dissolved iron concentrations in the world ocean? Mar Chem 57:137-161

Karl DM (1999) A sea of change: biogeochemical variability in the North Pacific Subtropical Gyre. Ecosystems 2:181-214

Karl DM (2002) Nutrient dynamics in the deep blue sea. Trends Microbiol 10:410-418

Karl DM (2007a) The marine phosphorus cycle. In: Hurst CJ, Crawford RL, Garland JL, Lipson DA and others (eds) Manual of environmental microbiology, 3rd edn. Am Soc Microbiol, Washington, DC, p 523-539
Karl DM (2007b) Microbial oceanography: paradigms, processes and promise. Nat Rev Microbiol 5:759-769

Karl DM, Lukas R (1996) The Hawaii Ocean Time-series (HOT) program: background, rationale and field implementation. Deep-Sea Res II 43:129-156

Karl DM, Letelier R, Hebel DV, Bird DF, Winn CD (1992) Trichodesmium blooms and new nitrogen in the North Pacific gyre. In: Carpenter EJ, Capone DG, Rueter JG (eds) Marine pelagic cyanobacteria: Trichodesmium and other diazotrophs. Kluwer Academic Publishers, Dordrecht, p 219-237

Karl DM, Letelier R, Tupas L, Dore J, Christian J, Hebel D (1997) The role of nitrogen fixation in biogeochemical cycling in the subtropical North Pacific Ocean. Nature 388:533-538

Karl DM, Björkman, Dore JE, Fujieki L and others (2001) Ecological nitrogen-to-phosphorus stoichiometry at Station ALOHA. Deep-Sea Res II 48:1529-1566

Karl D, Michaels A, Bergman B, Capone D and others (2002) Dinitrogen fixation in the world's oceans. Biogeochemistry 57-58:47-98

Karl DM, Beversdorf L, Bjorkman K, Church MJ, Martinez A, DeLong E (2008) Aerobic production of methane in the sea. Nat Geoscience 1:473-478

Kustka A, Sañudo-Wilhelmy S, Carpenter EJ, Capone DJ, Raven JA (2003) A revised estimate of the iron use efficiency of nitrogen fixation, with special reference to the marine cyanobacterium Trichodesmium spp. (Cyanphyta). J Phycol 39:12-25

- Letelier RM, Karl DM (1996) Role of Trichodesmium spp. in the productivity of the subtropical North Pacific Ocean. Mar Ecol Prog Ser 133:263-273

Longhurst A (1998) Ecological geography of the sea. Academic Press, San Diego

Lovelock JE, Rapley CG (2007) Ocean pipes could help the Earth to cure itself. Nature 449:403

- McAndrew PM, Bjorkman KM, Church MJ, Morris PJ, Jachowski N, Williams PJ le B, Karl DM (2007) Metabolic response of oligotrophic plankton communities to deep water nutrient enrichment. Mar Ecol Prog Ser 332:63-75

Mills MM, Ridame C, Davey M, La Roche J, Geider RJ (2004) Iron and phosphorus co-limit nitrogen fixation in the eastern tropical North Atlantic. Nature 429:292-294

Moutin T, Karl DM, Duhamel S, Rimmelin P, Raimbault P, Van Mooy BAS, Claustre H (2008) Phosphate availability and the ultimate control of new nitrogen input by nitrogen fixation in the tropical Pacific Ocean. Biogeosciences 5: 95-109

Mulholland MR, Bronk DA, Capone DG (2004) Dinitrogen fixation and release of ammonium and dissolved organic nitrogen by Trichodesmium IMS101. Aquat Microb Ecol $37: 85-94$

Powell H (2008) What are the possible side effects? Oceanus 46:14-17

> Rees AP, Law CS, Woodward EMS (2006) High rates of nitrogen fixation during an in situ phosphate release experiment in the Eastern Mediterranean Sea. Geophys Res Lett 33:L10607

Rees AP, Nightingale PD, Owens NJP, PML FeeP Team (2007) FeeP-An in situ $\mathrm{PO}_{4}{ }^{3-}$ and $\mathrm{Fe}^{2+}$ addition experiment to waters of the sub-tropical north-east Atlantic. Geophys Res Abstr 9:01440

Richardson K (1997) Harmful or exceptional phytoplankton blooms in the marine ecosystem. Adv Mar Biol 31:301-385

Ridame C, Guieu C (2002) Saharan input of phosphate to the oligotrophic water of the open western Mediterranean Sea. Limnol Oceanogr 47:856-869 
Rodier M, Le Borgne R (2008) Population dynamics and environmental conditions affecting Trichodesmium spp. (filamentous cyanobacteria) blooms in the south-west lagoon of New Caledonia. J Exp Mar Biol Ecol 358:20-32

Sañudo-Wilhelmy SA, Kustka AB, Gobler CJ, Hutchins DA and others (2001) Phosphorus limitation of nitrogen fixation by Trichodesmium in the central Atlantic Ocean. Nature 411:66-69

Shepherd J, Iglesias-Rodriguez D, Yool A (2007) Geo-engineering might cause, not cure, problems. Nature 449:781

Socolow RH, Pacala SW (2006) A plan to keep carbon in check. Sci Am 295:50-56

Sunda WG (1991) Trace metal interactions with marine phytoplankton. Biol Oceanogr 6:411-442

Takahashi T, Feely RA, Weiss RF, Wanninkhof RH, Chipman DW, Sutherland SC, Takahashi TT (1997) Global air-sea flux of $\mathrm{CO}_{2}$ : an estimate based on measurements of sea-air $\mathrm{pCO}_{2}$ difference. Proc Natl Acad Sci USA 94:8292-8299

Thingstad TF, Krom MD, Mantoura RFC, Flaten GAF and others (2005) Nature of phosphorus limitation in the ultraoligotrophic eastern Mediterranean. Science 309:1068-1071

Uz BM (2007) What causes the sporadic phytoplankton bloom southeast of Madagascar? J Geophys Res 112:C09010

Submitted: February 1, 2008; Accepted: May 26, 2008
Van Mooy BAS, Rocap G, Fredricks HF, Evans CT, Devolt AH and others (2006) Sulfolipids dramatically decrease phosphorus demand by picocyanobacteria in oligotrophic marine environments. Proc Natl Acad Sci USA 103: 8607-8612

White A, Spitz Y, Karl DM, Letelier RM (2006) Flexible elemental stoichiometry in Trichodesmium spp. and its ecological implications. Limnol Oceanogr 51:1777-1790

White AE, Spitz YH, Letelier RM (2007) What factors are driving summer phytoplankton blooms in the North Pacific Subtropical Gyre? J Geophys Res 112:C12006

> Wiegert RG, Penas-Lado E (1995) Nitrogen-pulsed systems on the coast of northwest Spain. Estuaries 18:622-635

> Wu J, Sunda W, Boyle EA, Karl DM (2000) Phosphate depletion in the western North Atlantic Ocean. Science 289: 759-762

Wu J, Boyle E, Sunda W, Wen LS (2001) Soluble and colloidal iron in the oligotrophic North Atlantic and North Pacific. Science 293:847-849

Zohary TB Herut B, Krom MD, Fauzi FC and others (2005) Plimited bacteria but $\mathrm{N}$ and $\mathrm{P}$ co-limited phytoplankton in the Eastern Mediterranean-a microcosm experiment. Deep-Sea Res II 52:3011-3023

Proofs received from author(s): July 9, 2008 